\title{
USE OF NEURAL NETWORKS IN RISK \\ ASSESSMENT AND OPTIMIZATION \\ OF INSURANCE COVER IN INNOVATIVE \\ ENTERPRISES
}

\author{
RYSZARD PUKAŁA
}

\begin{abstract}
A B S T R A C T
The scientific objective of the paper is to present the findings of a study into the use of artificial neural networks in quantifying activity related risks of an innovative enterprise and to optimize its insurance cover in order to minimize the probable financial losses whenever they materialize. The Kohonen network involving the activation of 51 input variables was applied in the study. The outcomes of the stimulation for the given set of variables made it possible to determine the probability of a threat occurring in the classes. The results of the analysis were used to prepare an optimal insurance cover for the activities of the innovative company. The research findings are suitable for use in risk theory as well as in issues relating to entrepreneurship and insurance. The analytical device employed can also be put to practical use as a support tool in corporate risk management.
\end{abstract}

KEY WORDS

innovative enterprise, risk, neural networks, Kohonen networks, business insurance

DOI: 10.1515/emj-2016-0023
Corresponding author:

Ryszard Pukała

Institute of Economics and Management, State Higher School of Technology and Economics in Jarosław

e-mail: ryszard.pukala@interia.pl

\section{INTRODUCTION}

The contemporary market economy has been subjected to constant changes due to processes of globalisation, the recurring crisis, the economic downturn of recent years, the tearing down of national frontiers as well as the intensifying competition. These factors are, in today's market realities, key external factors affecting the business activities of enterprises ${ }^{1}$. Hence it is expected of them to skilfully adapt tasks and functions including methods of work organisation and management to

1 The enterprise is understood to mean a „unit (entity), that undertakes business activity with aim of meeting the needs of other social entities (individual and /or institutions) by producing goods and /or offering services, with the motivation for such activity being the desire to gain material benefits and it is conducted independently at the risk of its owner(s)" (Sudol, 2006). a radically changing business environment being the key players in a market economy. Their efficient adaptation to prevailing conditions (their complexity, structure, and dynamics) and the demands of a market economy determines the business outcomes and potentials for development in each case. Corporate adaptability can be observed, amongst other things, through the implementation of various innovative undertakings. It needs to be emphasized that the term "innovation” covers a very broad spectrum of concepts and refers to varied fields of life and business. The focus of this study, however, will be on economic and organisational aspects of the existence of an innovative enterprise. Contextually, therefore, it should be stressed that in the realities 
of our modern world, where information flow is virtually uninhibited, any company wishing to elevate its competitiveness or at least maintain its standing position must continually undertake technical improvements. Thus, the isolation of a group of innovative enterprises is not always justified as in an enterprise, innovative activities are inherent parts of the general activity and guarantee its survival as well as effective response to market changes. Innovation is ,a specific tool for entrepreneurs, with the help of which they create opportunities to develop new businesses or provide new services from existing changes" (Drucker, 1992, p. 29). Consequently, the introduction of changes only serves as a call to duty for every entrepreneur, as such, there is no need to isolate any specific category of innovative enterprises.

All companies, including the innovative ones, function in risky conditions. Risk is one of the primary economic phenomena. Every market participant is exposed to it and counteracting risk materialization is one of the elements of managerial efficiency, which is a relationship between making correct decisions that the management board bears responsibility for and information received (including, as regards risk), understood as an outlay. This applies particularly to business entities, where levels of savings and accumulated capital are generally insufficient to continue their business activities in the event of risks destabilizing their operations. Risk management and the eventual minimization of financial losses associated with its occurrence becomes hugely significant in such circumstances. Efficient risk management in corporate activities thus becomes an indispensable component of the business activity. It is also a process that is subject to continuous changes over time, which places on companies executives series of obligations aimed at risk limitation and optimum protection of companies against its negative consequences.

We need to emphasize that efficient corporate management, taking account of operating risk management, concerns the identification of various types of risk an innovative enterprise has to deal with as well as measuring and controlling risk levels. Risk management can, after all, only be talked about if it is measurable and quantifiable. Artificial neural networks, which are currently in use in many scientific fields can, amongst others, also be applied in this respect. Their primary benefits include „independent programmability" in the learning process, ability to generalize acquired knowledge and their relatively high resistance to errors of measurement. The biggest advantage of neural networks is that they allow the presentation of nonlinear dependences and the solving of problems for which there are difficulties in defining the causeeffect relationships. These features allow for their application in processes of optimizing risk management in the activities of innovative enterprises. The results of optimization, on the other hand, serve as the basis for introducing mechanisms for risk transfer in the form of insurance.

The scientific objective of this paper is to present the findings of studies that illustrate the possibilities of applying artificial neural networks in the process of optimizing the business risks of an innovative enterprise and its further curtailment with the use of insurance instruments. The following research hypothesis were formulated for the purpose of the study:

1. Artificial neural networks are effective tools of optimization in quantifying risks in innovative enterprises.

2. Minimizing the effects of risks with the likelihood of occurrence improves the management process and enhances business activities of an innovative enterprise.

To verify the research hypotheses, identification was carried out of the business risks in key areas of activities of an innovative enterprise. Relying on expert assessment, a quantification of each was undertaken from the view-point of the potential threats of disruption they may cause. To carry out the optimization studies, the Kohonen networks were applied, thus activating 51 input variables. The results of the simulation conducted on the set of variables made it possible to determine the probability of a threat in each class. The risks identified in the optimization process served as a base material for developing hierarchical insurance instruments, whose aim was to minimize losses associated with the materialization of business risks in an innovative enterprise.

\section{LITERATURE REVIEW}

Innovation as an issue in business has been the concern of research studies since the mid 20th century. It was then given a definition by Schumpeter (1960), who stated that it is:

- the introduction of a new product,

- the introduction of a new method of production (process innovation), 
- the opening of new market outlets,

- the opening of a new supply market,

- the introduction of a new organisation.

The above-mentioned five types of innovation indicate that it was associated with novelties introduced in a company's life. Subsequent years witnessed innovative issues being studied on a wider scale by economists, thus paving the way for a broader definition of a corporate business that can be referred to as innovative. While Allen (1966) affirms that innovation is the introduction of new products, processes or procedures for a wider usage, Whitfield (1979) points out that innovation is any form of modification that is based on the assimilation of knowledge transfer. Another idea with a very broad significance is that of Rogers (2003), which states that innovation is the introduction of new products, processes or procedures for a wider usage. Barnett provided a different definition of innovation, based on the premise that it is any concept, idea, attitude, position or thing, whose quality distinguishes it from all others existing till date (Borowski, 2011). Innovation is also explained as a process of creative application of knowledge, transformation of knowledge owned by the company or secured externally into new products, services or processes (Cavagnoli, 2011).

Polish researchers have also devoted much time to the issue of innovativeness. Zastempowski (2010) focusses on the significance of innovation in corporate business in continuously transforming market situations. While Pichlak (2012) emphasizes the conditions that companies ought to meet to fulfil the criteria of innovativeness. Marciniak (2010) illustrates the links between innovativeness and acquisition of permanent competitive advantage in globalized markets. Wiśniewska’s (Wiśniewska \& Janasz, 2012) publication discusses the complex issues of innovation and corporate innovativeness in respect of challenges caused by smart strategies and sustainable development. Globalisation enhances the expansion of international economic ties and international cooperation. Common technical joint ventures and scientific research are also developed. This requires knowledge of existing regularities, mechanisms, innovative and development trends, re-evaluation of assessment criteria, identification of barriers to innovation as well as the functional principles of stimulators.

The concept of innovation has been the subject of analysis not only for individual scientists but also for institutions. One of the most important to be mentioned is the European Commission, which in its policy of support for businesses has been emphasising their innovativeness for years. According to the handbook issued by the European Commission, the Oslo Manual, an innovative enterprise is that which has introduced at least one technological innovation over the study period, which is usually three years. This could be a new or an improved product, a new or improved process, which from the said company's point of view is a novelty. Based on this definition a large group of companies can be classified as innovative. This will indeed serve as the leading definition in respect of analyses conducted for the purpose of this paper.

Enterprise development is an indispensable process for survival and continued existence in markets. This leads to changes in the level and structure of the company's component parts. Enterprise development depends on both external and internal factors that define companies' existence. The external factors, namely those, on which the enterprise has limited possible influence, constitute the widely understood environment, from whose resources the company benefits and satisfies its needs. The internal factors, on the other hand, namely factors on which the enterprise has direct influence and which determine the company's development. Both groups create, on a closer diagnosis, a broad spectrum of risks that could threaten businesses. Skilful risk identification and its efficient management undoubtedly improve companies' activities, allowing for the achievement of better financial results and very often a competitive edge.

Risk is defined as a state of uncertainty, during which a specific event, action or inaction could affect the capacity to achieve set objectives. The concept of risk is closely tied to the notion of change, uncertainty or decision. Risk, in the economic sphere, including corporate activities, is defined specifically from the view-point of achieving or non-achievement of expected economic and financial results, while its occurrence is a consequence of existence in the economic space of free markets. The concepts of risk and uncertainty exist and intertwine with each other both in everyday language and in theories of economics ${ }^{2}$. The author of basic distinctions in his fundamental studies on labour risks, risk, uncertainty and profit, is Knight (1921). Knight described risk and uncertainty as two distinctive phenomena, which

\footnotetext{
2 For example, the American Committee of Insurance Terminology defines risk as the uncertainty in achieving the results of an event, to which there exist two or more possible outcomes (Qutreville, 1998).
} 
have continued to stir debates till date. Researches into risk have yielded several trends that relate to varied aspects of the theory. In their studies, representatives of the theory of the objective expected utility and game theory von Neumann and Morgenstern (1944), Markowitz (1959), and Baumol (2007) focused on the objectification of the assessment of situations in which the decision-maker has to make a choice of decision options, the form of the decision taken as well as its results. An example of the application of the objective components of risk theory could be the theory of games, which is used to analyse the behaviour of market players. Adherents of the theory of subjective expected utility are Ramsey (1926) and Aumann (1962), who drew prominent attention to the cognitive aspects of risk, had a different position on this matter. The next trend concerns a theory that was unrelated to the expected utility that was initiated by Schackle, Allais Wald. The theory of risk was also reflected in Tversky and Kahneman's (1979) experimental economics. Jajuga (2007), who precisely defined the process of risk management and demonstrated possibilities of its application in managerial processes in companies, banks, and insurance companies also contributed hugely to the development of the theory of risk.

All research trends into the theory of risk were concentrated on its theoretical aspects, but to a lesser extent referring to the practical applications of models or dependencies developed. In 1970s studies were undertaken that were aimed at practical using of risk as a state of uncertainty at making decisions. Another step was the development of an actuarial risk theory, formulated by the insurance sector, which undertook to control risk by means of elements of the probability theory (Sadowski, 1978). It was not until the actuarial theory of risk, developed by an insurance company, the first entrepreneurial field in which risk control was undertaken with the help of elements of probability theory, where attempts were made to develop a completely independent mainstream of researches (Borch, 1990). It is in the insurance business that risk issues are accorded an elaborate consideration. They are, on the one hand, business entities whose primary activity is to take over the risks of the insured and manage it in a way to facilitate the fulfilment of their commitments to customers. Insurance companies, on the other hand, are independent business entities that must take care of their economic accounting and make use of risk management mechanisms in this regard. Risk is, therefore, the subject of all economic endeavours,
(Qutreville, 1998). Risk, from the objective perspective, means exposure to adversities (Vaugham, 1997). An important element, from the insurance view-point, is the reference made to the expected outcomes, as a result of which risk is defined as the spread of factual and expected results (RonkaChmielowiec, 1998), where the degree of deviation of results from the medium, or as the probability of achieving values other than that expected is determined. Contemporary research studies concentrate mainly on the practical aspects of risk management. Monkiewicz et al. (Monkiewicz \& Hadyniak, 2010) indicate that insurance companies protect their resources and enhance the security level of market turnovers, thus impacting on their market values. The efficient use of insurance in risk management programs requires access to ever higher skills and competencies. The author highlights the effective use of insurance as an instrument of corporate management (Monkiewicz \& Gąsiorkiewicz, 2011). A much wider approach to the use of insurance in business was presented by Kwiecien (2010), who brought to prominence the practical significance of insurance in risk management by business operators, i.e., clients of insurance companies.

It can, thus, be observed that the issue of risk management by companies and the limitation of its impacts through the use of insurance have been the subject of multilateral research over several decades. This, undoubtedly, indicates the significance of such issues in corporate business practices, including innovative enterprises.

The next area of concern of the elaborated research studies is artificial neural networks. As noted by Tadeusiewicz (2007), the sudden interest in neural networks is neither due to coincidence nor a fad. Neural networks are indeed convenient tools, successfully being put to use in an unexpectedly wide range of issues, in disciplines so different from each other like finance, medicine, engineering applications, geology, and physics. They can practically be applied wherever problems arise not only in data processing and analysis, but also in their prediction, classification, and control.

The start of developments in neural networks can be credited to McCulloch and Pitts (1943), who were the first to demonstrate mathematical descriptions of a nerve cell, linking it with the issue of data processing. The presented model had huge impacts on subsequent developments in this scientific discipline. Several years later, Hebb (1949) introduced 
the concept of neuron teams and was the first to propose a method of learning networks, which involves exchanging connecting weights between neurons. The first networks with feedback units appeared in the 1980s but in 1982, Kohonen proposed a new algorithm for artificial neural networks, which were code-named Kohonen networks (Kohonen, 1982). It can be briefly characterized as a self-learning network with in-built competition and a neighbourhood mechanism (Lasek \& Myzik, 2004). They are applicable in various fields of scientific studies and were involved, among other things, in geology (Chang et al., 2002), aviation (Czechowicz \& Mikut, 2007), environmental protection (Licznar \& Łomotowski, 2006) and in public administration (Muczyński, 2009). A very significant factor is the

Tab. 1. Key business risks of innovative enterprises

\begin{tabular}{|c|c|c|c|}
\hline $\begin{array}{l}\text { AREA } \\
\text { (N) }\end{array}$ & \multicolumn{2}{|l|}{$\begin{array}{l}\text { RISK } \\
\text { (X) }\end{array}$} & $\begin{array}{c}\text { RANGE } \\
\text { (W) }\end{array}$ \\
\hline \multirow{4}{*}{$\begin{array}{l}\text { TECHNICAL } \\
\left(\mathrm{N}_{1}\right)\end{array}$} & lack of know how in practical application of technologies & $x_{1}$ & 0.60 \\
\hline & legislative changes that eliminate or restrict possible use of a technology & $x_{2}$ & 0.55 \\
\hline & $\ldots$ & $\ldots$ & $\ldots$ \\
\hline & inability of use of technology in other alternative spheres & $x_{9}$ & 0.20 \\
\hline \multirow{4}{*}{$\begin{array}{l}\text { ECONOMIC } \\
\left(\mathrm{N}_{2}\right)\end{array}$} & lack of cash-flow/insolvency & $x_{10}$ & 0.60 \\
\hline & $\begin{array}{l}\text { loss of influence over the company/company ownership in case of companies } \\
\text { with foreign capital financing }\end{array}$ & $x_{11}$ & 0.55 \\
\hline & $\ldots$ & $\ldots$ & $\ldots$ \\
\hline & inappropriate feasibility studies & $x_{21}$ & 0.05 \\
\hline \multirow{3}{*}{$\begin{array}{l}\text { TIME } \\
\left(\mathrm{N}_{3}\right)\end{array}$} & exploiting the needs of customers & $x_{22}$ & 0.30 \\
\hline & improving the product & $x_{23}$ & 0.20 \\
\hline & time duration from product conception to its commercialisation & $x_{24}$ & 0.15 \\
\hline \multirow{4}{*}{$\begin{array}{l}\text { ABSORBENCY } \\
\left(\mathrm{N}_{4}\right)\end{array}$} & incorrect definition of product features and its absorbency & $x_{25}$ & 0.40 \\
\hline & proper definition of the target market & $x_{26}$ & 0.35 \\
\hline & $\ldots$ & $\ldots$ & $\ldots$ \\
\hline & supply of such products that generate further needs & $x_{29}$ & 0.15 \\
\hline \multirow{4}{*}{$\begin{array}{l}\text { ORGANISATIONAL } \\
\qquad\left(\mathrm{N}_{5}\right)\end{array}$} & qualifications of staff & $x_{30}$ & 0.50 \\
\hline & order management & $x_{31}$ & 0.45 \\
\hline & $\ldots$ & $\ldots$ & $\ldots$ \\
\hline & strikes and labour unrest & $x_{39}$ & 0.05 \\
\hline \multirow{4}{*}{$\begin{array}{c}\text { OPERATIONAL } \\
\left(\mathrm{N}_{6}\right)\end{array}$} & business interruptions & $x_{40}$ & 0.60 \\
\hline & inefficient plans of business restoration & $x_{41}$ & 0.55 \\
\hline & $\ldots$ & $\ldots$ & $\ldots$ \\
\hline & liabilities and claims & $x_{46}$ & 0.30 \\
\hline \multirow{4}{*}{$\begin{array}{l}\text { COMPETITION } \\
\left(\mathrm{N}_{7}\right)\end{array}$} & hostile takeovers & $x_{47}$ & 0.40 \\
\hline & theft of property rights & $x_{48}$ & 0.35 \\
\hline & $\ldots$ & $\ldots$ & $\ldots$ \\
\hline & sabotage & $x_{51}$ & 0.15 \\
\hline
\end{tabular}
studies, where they can be used, among other things, (Tadeusiewicz, 1998) for:

- predicting and forecasting of specific events based on data from the past (for example, a bear and bull market on the stock exchange, financial results),

- classification (for example, of companies based on the financial condition or degree of unemployment threat in the analysed regions),

- creating financial or production analysis as well as controlling business processes,

- searching for optimal solutions to economic issues (for example, the so-called the travelling salesman problem).

Utilization of Artificial Neural Networks in various areas of human activity has created new possibilities for analysing and forecasting the future. At the same possibility to apply neural networks in economic 
time, risks that can falsify the results of analyses have emerged. The main factor that disorganises conducted studies is susceptibility of the network to overlearning (emergence of the fatigue phenomenon). In such case, initial data processing is required, e.g. normalisation of values of a learner-file size (Larose, 2006).

Alongside developments in researches into neural networks, publications linking various areas started emerging, including the use of the Kohonen networks for the division of provinces into regions of similar conditions for agricultural production (Zaród, 2012), in explorations concerning territorial units (Lasek \& Myzik, 2004), to value contractual options at the WIG20 (Kraszewska, 2011) or in other areas. There is, however, a dearth of research studies in respect of the multi-dimensional analysis of innovative enterprises, risk, insurance and artificial networks. Hence an additional objective of the author is to undertake studies that are of interdisciplinary nature, linking all of the aspects analysed, thus creating a new added value in this field. The results obtained will be of theoretical analysis in nature, but the methodology thus developed can be of practical use in risk management process through the application of artificial neural networks in business activities.

\section{ASSUMPTIONS AND RESEARCH METHODS}

In analysing the functioning of innovative enterprises, it should be emphasized that risk applies to every segment of their activities. The following stages, namely idea, incubation, growth, maturity, and decline, are identifiable in their case. Each of these stages is subjected to significant levels of risk. Innovative ventures come along with huge risks, especially at their early stages, hence not many of them go beyond the incubation stage to achieve success. It can rightly be said that skilful risk management results in innovative endeavours are transformed into innovative enterprises. Surmounting risk enables innovative enterprises to proceed to the incubation stage, and further growth is relatively quiet.

There are no innovative endeavours devoid of risks. Any entrepreneur that initiates an innovative project ought to have the fore-knowledge of what areas are risk prone, which constitute threats to his/ her project and those that serve as opportunities for growth. Areas of risks in respect of innovative projects are much more extensive and complex than in other undertakings, hence, an innovative entrepreneur ought to pay specific attention to key areas of risk associated with current activities.

An optimal method of identification is to create a risk map based on risk analysis carried out by specialists employed at a company or outsourced to a specialist entity.

Table 1 is an illustration of risk types associated with the functioning of an innovative enterprise.

The risks were grouped into key areas of business activity (N1 - N7). Each of the areas was divided into subcategories, which were, in accordance with the expert system, assigned a rank of significance reflecting the possible impact of a given subcategory on the entire activities of the enterprise.

Arranging particular risk categories can take place on the basis of an analysis of historical data concerning materialisation of particular risk types in the past and an individual assessment performed by specialists dealing with this area of corporate operations. An important source of information expedient at conducting the arrangement can comprise of reports of institutions specialising in corporate risk identification and assessment (e.g. „Corporate Risk and Insurance Management in Poland" report prepared by Aon Risk Solution). Beyond doubt, a dynamic process of changes related to the development of a company, entering new areas of operation and innovative activity itself, which can be performed with the use of ever more modern technologies, is hazardous for the process of risk identification and arrangement. Low level of knowledge among experts in the field of corporate risks can also constitute a problem.

The ranking range for a given area was between 0.00 and 1.00 , with the minimum progressive step of 0.05 . The aggregated data were used as input (vectors) data for further analysis, which involved the application of artificial neural networks.

Resolution of economic problems often requires the use of neural networks due to their complexity and nonlinear occurrences. Their application permits (Kasperski, 2003):

- a comprehensive unravelling of optimization issues, obtaining overt solutions to quantitative and qualitative problems in changing market conditions,

- a fast and efficient implementation of a number of variants based on different assumptions.

The self-organising Kohonen networks, in which 
each learning vector from the input layer is connected to a neuron from the output layer, but avoiding any connections between components of the same layer was applied in optimization studies in this fore-going study. The connections were assigned weights with value ranges of $[0,1]$, (Larose, 2006). The weights were assigned initial values with the use of varied algorithms. Such values can be assigned randomly. The Kohonen learning network proceeds in an iterative manner. The so-called neural network learning stage ends after acquainting the network with cases of all learners, which consists of several individual steps. Each step involves the analysis of the case of a single learner, the rivalry of individual neurons, followed with the modification of the vector weight of the winning neuron, including its neighbouring neurons. The neuron for whom the signal is obtained, at its input stage, is the strongest and accepted as the winning neuron. The output value of this neuron is usually defined as the moment where the Euclidean distance between the weighted vector and the input vector attains its highest (usually the smallest in the case of the Euclidean distance) value. The weights of the winning neuron and its neighbours are modified in order to minimize the distance between the presented input vector and the weighted vector. We are dealing with competitive learning in this case of a network. This means that the user is in disposition only of input patterns, although there exist their corresponding expected values. The task of the network in the learning process is to produce such patterns. The network aims to isolate input date classes that will represent the dominant features from amongst the input vectors.

The applied neural network is a single directional feed-forward type of network, in which each neuron is connected to all components of the n-dimensional input vector $\mathrm{x}$. The weights of neuron connections forms a vector $w i=[w i 1, w i 2, \ldots, w i n] T$. The vectors of the input signals $\mathrm{x}$ precedes the normalized learning process $\|x\|=1$, which can be written as (http://iisi.pcz.pl/nn/samoorg.php?art=2),(1):

$$
x_{i}=\frac{x_{i}}{\sqrt{\sum_{i-1}^{n}\left(x_{i}\right)^{2}}}
$$

Having stimulated the network with the input vector $\mathrm{x}$ of the competition algorithm, the neuron whose weight differs from the corresponding components of the said vector and with the least value wins. The winning neuron w-ty should meet the following criteria (2): $d\left(x, w_{w}\right)=\min _{1<i<n} d\left(x, w_{i}\right)$

where $d(x, w)$ is the distance in terms of the selected metrics between vectors $n$ and $w$.

A topological neighbourhood $S w(n)$, whose radius decreases over time is acceptable in the proximity of the winning vector. Next, the winning neuron and other surrounding ones are subjected to adaptation in accordance with the Kohonen rule (Kohonen, 1995), (3):

$w_{i}(n+1)=w_{i}(n)+\eta_{i}(n)\left[x-w_{i}(n)\right]$

for $\mathrm{i} \in S w(n)$, where $\epsilon i(n)$ is a learning coefficient of the i neuron from the $S w(n)$ neighbourhood in an $n$ moment. The value of $\epsilon(n)$ decreases along with the distance of a neuron to the winner. Weights of neurons from outside the $S w(n)$ neighbourhood are not subject to changes.

$$
w_{i}(n+1)=w_{i}(n)+\eta_{i}(n)\left[x-w_{i}(n)\right]
$$

The basic learning algorithm in the Kohonen networks has the form (4):

where:

- $i$ - element of a vector,

- $n$ - number of learning stage.

The learning coefficient and each of the neurons have, in this formula, been separated from their distances in respect of the vector $\mathrm{x}$, which was taken care of in the neighbourhood function $\mathrm{G}(\mathrm{i}, \mathrm{x}),(5)$.

$G(i, x)=\exp \left(-\frac{d^{2}(i, w)}{2 \lambda^{2}}\right)$

The weights of the isolated winning neuron have been modified on the Kohonen maps (Kohonen, 1995) using the binary neighbourhood function (6):

$$
G(i, x)=\left\{\begin{array}{lll}
1 & \text { dla } & d(i, w) \leq \lambda \\
0 & \text { dla } & \text { pozostalych }
\end{array}\right.
$$

where:

- $d(i, w)$ - distance between neurons in the network space,

- $\lambda$ - neighbourhood radius decreasing to zero during learning.

In the Kohonen classical algorithm, the neighbourhood function usually assumes the form of Gaussian function $G(i, x)$, which is defined thus (7).

$d(i, w)$ denotes the Euclidean distance between the winning neuron $w$ and $i$-th neuron. The coefficient is the neighbourhood radius, with values decreasing 


$$
G(i, x)=\exp \left(-\frac{d^{2}(i, w)}{2 \lambda^{2}}\right)
$$

over time. This is a rectangular type of neighbourhood. The degree of adaptability of neighbourhood neurons to the winning one during the learning process determines both the Euclidean distance $d(i, w)$ and the radius of the neighbourhood.

Simulations using the Kohonen network will be carried out in several stages. During the first stage, calculations will be carried out on 51 risks (x) in 7 classes (N) giving 567000 vectors in total. The simulation will result in isolating classes, within which the risks are most likely to occur. The probability of occurrence of certain risks within a group will also be calculated based on the number of vectors. The data obtained will serve as the base for establishing a group of risks, to which innovative enterprises are most vulnerable. The results of the simulation will be used to create a risk map, on which they will be classified as risks with the highest level of threat. The next stage of the simulation is to carry out calculations with the highest probability of occurrence, excluding those classes obtained at the first stage. The results obtained at this stage will be classified on the map as moderate risks. Subsequent stages will follow the same pattern, while the results will be marked on the risk map in areas with decreasing threat, based on their likelihood of occurrence.

The next stage will involve placing insurance products or other instruments of risk transfer that minimize the risks associated with activities of an innovative enterprise on the classes isolated as a result of the simulation.

\section{ASSESSING THE LIKELIHOOD OF RISK OCCURRENCE IN THE ACTIVITIES OF INNOVATIVE COMPANIES IN LIGHT OF THE AUTHOR'S STUDIES}

Every business activity has its inherent risk and is capable of destabilizing any endeavour should it occur. For an innovative enterprise, the identification and management of such risk could be crucial for the safety of its existence. An important factor is the "preemptive" approach to avoiding risk-related consequences through the use of tools that enable their skilful management and protection against such consequences. This can be achieved through the implementation of risk management mechanisms and, among other things (Kaszuba-Perz \& Perz, 2010), through:

- integrating risk management with strategic planning, where the company specifies its "appetite" for risk at that stage of strategic planning,

- the inclusion of risk indicators in the company's internal evaluation system,

- taking into consideration the effects of diversification of various types of risks in the entire company,

- the conscious choice of varied forms of reaction to existing risks (acceptation, avoidance, sharing, and limitation).

A key element in all the above-mentioned cases is the correct quantification of the risks and determination of their probability of occurrence. This enables the selection of an optimal means of counteracting the effects of risk. This was also the purpose of the simulation exercises undertaken using the Kohonen network.

An iterative algorithm is utilised in the learning process of the Kohonen network. Learning begins from a random weight of output neurons. Values of explanatory variables are introduced in the next stage to network inputs. In response to an input signal, network neurons begin rivalling one another, as a result of which an output neuron is found, whose weights are most similar to the vector of input values. Along with the winning neuron, weights of neigbouring neurons - assigned on the basis of an assumed network typology pattern - are modified in an analogous way. During the learning process the learning coefficient and neighbourhood size coefficient become gradually decreased. In consequence, the learning procedure leads not only to the allocation of cluster centres in a multidimensional input space, but also orders neurons in such a way that neurons that represent centres located close to one another in the input space are located close to one another in a model of two-dimensional topological map. In practice, this means that the more similar two objects are to each other, the closer the corresponding neutrons will be found on a topological map (Muczyński, 2009).

In the case analysed in this study, calculations were carried out in several stages with regard to a set of 567 thousand vectors that reflect risk classes and ranks presented in Table 1.

On the basis of obtained data, a knowledge map 
Fig. 1. Distribution of Kohonen network vectors for key risks to innovative enterprise operations (for the set of 567000 vectors)

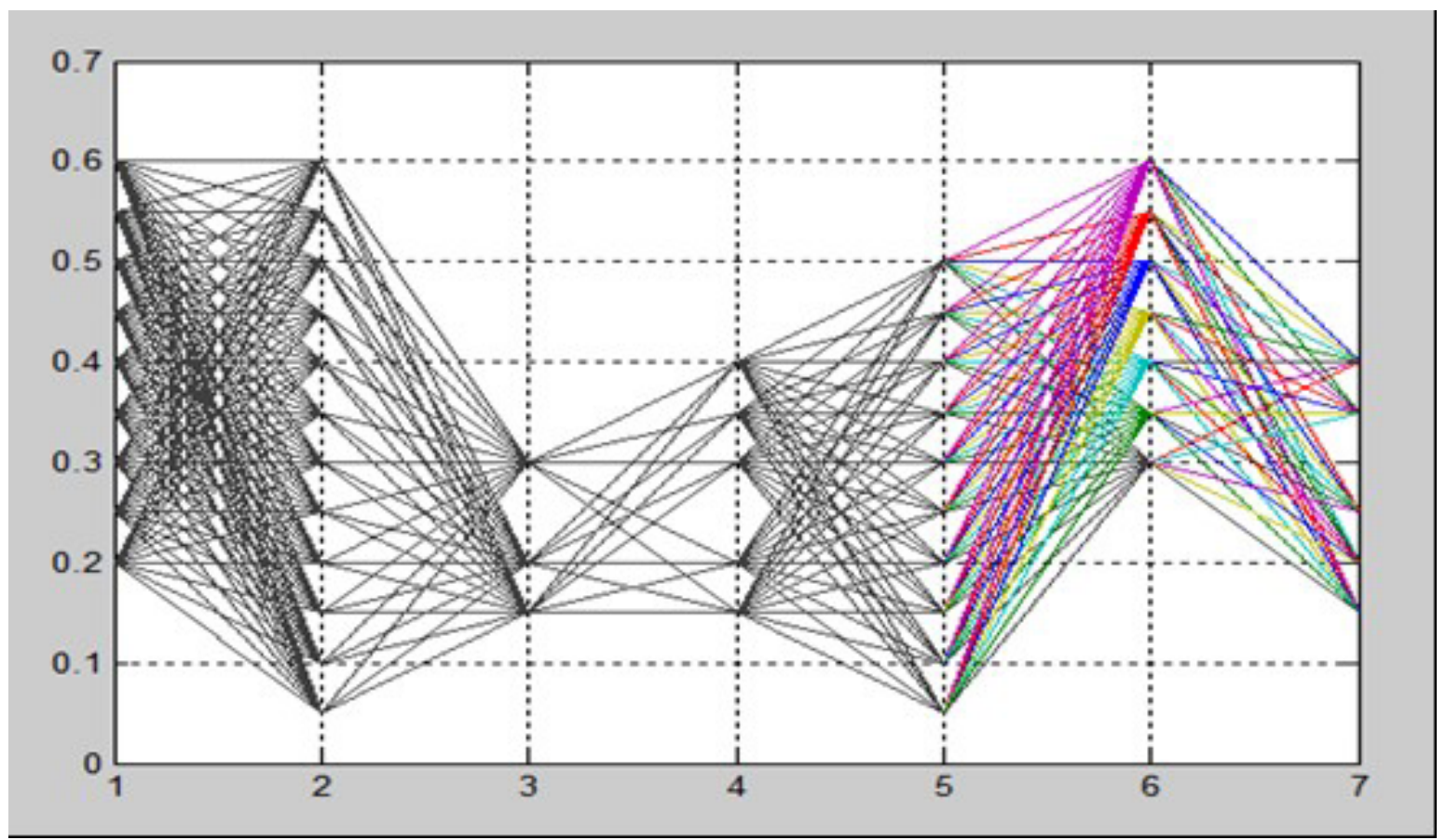

Source: own calculations using the MATLAB program.

was built, which defines probability of materialisation of key risks that determine the operation of an innovative enterprise. Another stage of analysis was to subject the data to a further, advanced analysis, aimed at identifying groups of risks that, if materialized, can contribute to the greatest losses suffered by an enterprise. Calculation results are presented in Figure 1. The conducted analyses have not found over-learning of neural networks, which means that results delivered are not burdened by irregularities.

Designations adopted in the abovementioned chart:

- Axis X - risk areas,

- Axis Y - ranks of identified risks.

On the basis of the simulations carried out at the first stage, the first group of risks was isolated, and among them, the risks with the highest probability of occurrence were identified. The results of the calculations are illustrated in Table 2.

The data obtained in the course of the simulations will enable the design of a map of risks in groups of the highest threat, with the probability of occurrence of the given risk being established (Fig. 2).

The risk with the most likely chance of occurrence ought to be, from the view-point of potential threats, „neutralized" at the first instance.

One of the most popular tools in this aspect is insurance, which is perceived by many entrepreneurs as an efficient instrument for the protection of corporate activities. Before undertaking a more detailed assessment, it is worth noting that two types of risks, from the security point of view, can be distinguished, namely:

- clean risks being the consequences of random events beyond our control or are unintended, whose effects can only cause, losses for example, fire, theft, car accident, etc.,

- speculative risks being the consequences of actions taken by us hoping that they would generate profits, for example, the purchase of shares on the stock exchange.

The objective of such classification is, first and foremost, to separate the insurable from the noninsurable risks and also to create groups of risks that can be legally regulated, which is a necessity and a general condition for drafting an insurance contract. It should be noted that insurance relies on the principle of risk sharing and in reference to future events, they are used to guarantee protection in case of clean risks ${ }^{3}$. Hence before the drafting of the final

3 The market is also abound with insurance products that offer protection also in cases of speculative risks, they are, however, omitted in this study due to their specific nature. 
Tab. 2. Risk classes with the highest probability of occurrence in the vector groups analysed

\begin{tabular}{|c|c|c|}
\hline No & $\begin{array}{c}\text { Number OF ISOlATEd ClAsses } \\
(\mathbf{N}, \mathbf{X})\end{array}$ & Number OF Vectors \\
\hline 1 & $\mathrm{~N}_{1}, \mathrm{x}_{2}$ & 137585 \\
\hline 2 & $\mathrm{~N}_{4}, \mathrm{x}_{4}$ & 176643 \\
\hline 3 & $\mathrm{~N}_{5}, \mathrm{x}_{2}$ & 44095 \\
\hline 4 & $\mathrm{~N}_{6}, \mathrm{x}_{5}$ & 40061 \\
\hline 5 & $\mathrm{~N}_{7}, \mathrm{x}_{2}$ & 168616 \\
\hline
\end{tabular}

Source: own calculations using the MATLAB program.

Fig. 2. Probability of occurrence of a risk in classes

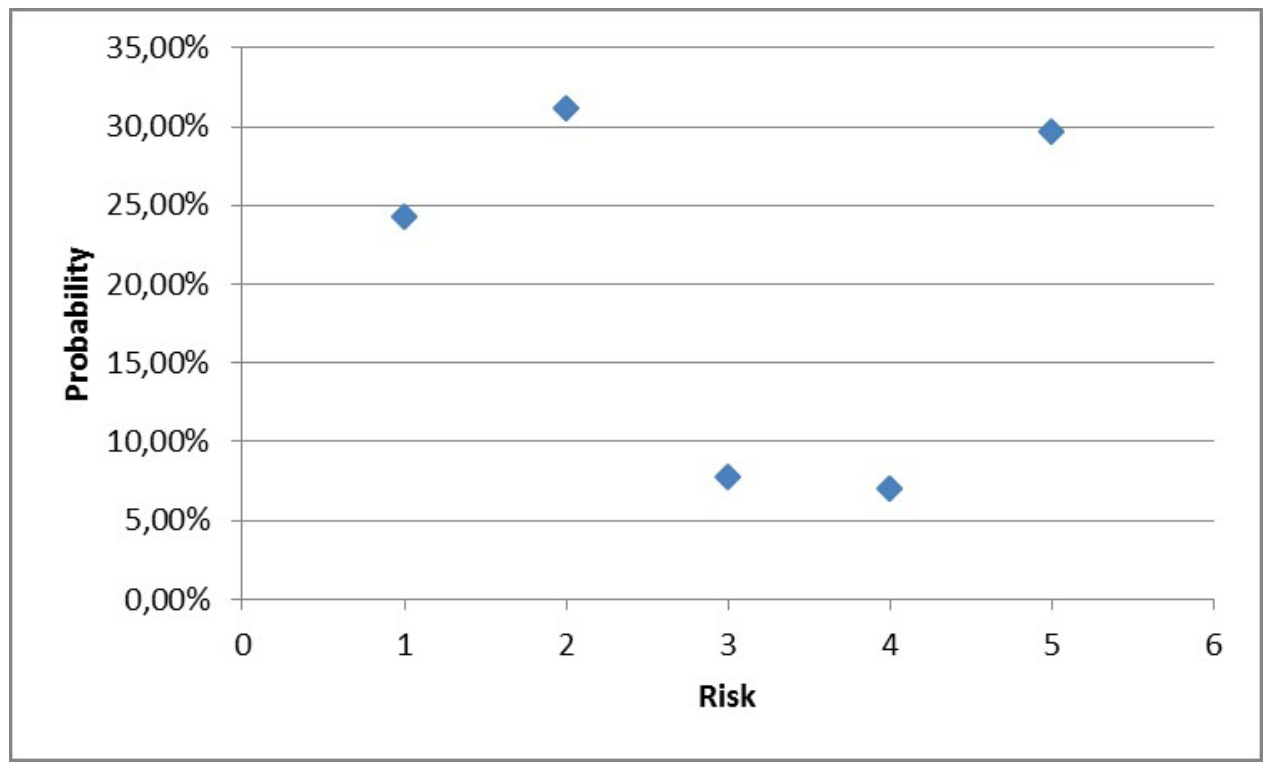

Source: own calculations using the MATLAB program.

insurance offer, the risk category should be verified from the perspective of its insurability.

The next simulation stage is conducting calculations for the set of 390357 vectors similarly to that previously described. The data obtained would allow the isolation of the next group of risks, whose impacts on the activities of an innovative enterprise is negligible.

It needs to be emphasized that each subsequent simulation is conducted on a smaller base of potential risks. During the simulation process, risks of the most likelihood of occurrence were firstly eliminated from the calculations to enable the adoption of the definite risk parameter. Each level of a given risk ought to be matched by actions from the company to minimize its impacts, thus enabling its efficient management. The relevant data is presented in Table 3.

It should be noted, however, that the level of risk transfer is assumed, as it depends on many factors attributable to the company. These include, among others:

- financial status,

- the level of indebtedness,

- the business sector the enterprise is in,

- dependence on the network of suppliers and subcontractors,

- implementation of risk management procedures,

- the range of instruments of risk transfer being put to use.

Hence, each company ought to decide, individually, about the degree and level of risk minimization making use of instruments of transfer available in the market.

\section{USE OF THE RESEARCH FINDINGS IN CORPORATE RISK MANAGEMENT BY MEANS OF INSURANCE}

The studies unequivocally indicate that the proper 
Tab. 3. Company activities relative to the level of risk

\begin{tabular}{|c|c|c|c|}
\hline SIMULATION & LEVEL OF RISK & $\begin{array}{c}\text { EXAMPLE OF LEVELS OF RISK } \\
\text { TRANSFER }\end{array}$ & ACTION \\
\hline Level I & very high & $100 \%$ & insure \\
\hline Level II & high & $80 \%$ & insure \\
\hline Level III & moderate & $60 \%$ & insure partly \\
\hline Level IV & average & $40 \%$ & retain \\
\hline Level V & low & $20 \%$ & don't insure \\
\hline
\end{tabular}

identification of risks in the activities of innovative enterprises could serve as a key factor in curbing business risks. The conscious and skilful transfer of risk to external entities, particularly those specializing in risk acceptance, such as insurance companies, becomes an important factor. It should be emphasised that insurance, from the view-point of entrepreneurs, is one of the optimal means of risk transfer. The competitive nature of insurance, compared to other methods of risk management, could be assessed from the angle of the relevance of criteria for evaluating and selecting risk management methods. The following criteria can be listed from the practical perspective (Pukała, 2013):

- effectiveness - insurance belongs to the group of compensatory methods, intended to compensate financially for losses incurred as a result of the risk that occurred,

- cost - insurance belongs to a financially attractive tool to ensure protection against the transfer of business-related risks. It is worth emphasizing that it facilitates the reduction of tax liabilities by writing off insurance premiums as deductibles,

- added benefits - the fact that insurance can, besides methods of risk transfer, ensure extra benefits for an entrepreneur, can be considered from two aspects:

- additional (non-compensatory) services by the insurer that could be helpful in managing the company, for example, assistance,

- benefits derivable from the insurance cover, other than the right to insurance claims or services, that give the entrepreneur the sense of security, thus encouraging them to take unconventional business decisions.

The risks identified in the course of the simulation exercise can be effectively handled through the use of insurance instruments. The scope (extent) of the resulting potential damage due to the materialization of events connected with the operations of the company is very wide, while the associated losses can lead to bankruptcy. Hence, the chief aim of an insurance policy is to minimize losses associated with turbulences in the company's activities and to provide support in areas of cost optimization in its operations. It should be noted that the current range of insurance cover offered business entities by insurers is elaborate, and the products on offer are becoming more sophisticated and „customized”. This is facilitated by the growing competition, the development of modern risk management mechanisms, both from the client and insurance company's perspective as well as the global transfer of know-how that enables the offer of programs that fully meet the expected needs of the customer (Pukała, 2014).

The analysis of the possibility of using a neural network, by means of which a group of risks that threaten a company's activities were identified as well as their likelihood of occurrence, has led to the conclusion that it is a very effective tool. The algorithm designed applying the Kohonen network is characterized by high efficiency and flexibility in conducting all stages of the simulation. This confirms the research hypothesis that neural networks enable the control of complex multidimensional issues that would in the course of using other methods hamper attempts to model non-linear functions consisting of a large number of independent variables. Another important benefit is their ease of use. Neural networks practically design models needed by the user independently as they learn from examples fed to them automatically. Neural networks can thus be put to use wherever there are tasks related to prediction, classification, and control.

\section{CONCLUSIONS}

The issue of risk management in innovative enterprises is currently very attractive in the light of existing risks attributable not only to a company but also its external environment. It is in this context that one should view the research studies that concentrated on identifying a company's businessrelated risks and the mechanisms being put to use to 
minimize their impacts.

In the light of the results obtained, the two research hypothesis adopted in preparation for the research study have been verified positively. The research methodology applied have yielded data, which unequivocally indicate that the methods are effective and can be efficiently applied in current business operations of innovative enterprises.

Here, it is worth emphasizing that analysis results delivered refer to three areas:

- risk assessment of innovative company, which:

- identified operating areas and risks characteristic for the entity's operation,

- arrange risks,

- create a data matrix for a further analysis with the use of the Kohonen network,

- offering insurance protection aimed at optimizing business operations and leading to limiting losses that can arise in the case most probable risks materialise, as part of which:

- identification and hierarchisation of the most probable risks has been carried out,

- proposals for management activities of an enterprise in the scope of applying insurance tools to limit financial losses in the case of risk materialization, taking account of the risk level,

- using a self-organising Artificial Neural Network (ANN) to classify risk of an innovative company to determine priorities as regards optimisation of its operations.

When viewed from this perspective, there is a need to stress the practical applications of the methodology in the current activities of companies, not limited to innovative, though, since the algorithm is universal in nature. It should also be noted that it embodies several trends in the area of risk theory, entrepreneurship, insurance and neural networks, which in some respect attests to its innovativeness.

What is also worth mentioning is the theoretical aspect of the analysis. Both the literature analysis and the findings contained in them clearly indicate that while each of the aforementioned fields of science is adequately covered nationally and internationally, there is, however, the dearth of studies that link all these disciplines. Attempts were made in the research to cover all of these areas. The findings obtained indicate the possibility of combining various areas of research and arriving at conclusions that will be multidisciplinary in nature. This would enable the expansion of fields of research and sharing of solutions between them. Similar approaches undoubtedly contribute to the even deeper analysis of the phenomena, which have, hitherto, been studied superficially or within a narrow context.

The designed methodology can serve as a model, and an inspiration for further research in interdisciplinary dimension within the disciplines suggested as well as in others of different areas of interest. It can also be a source of information for developing own ideas, which will undoubtedly enable the efficient exploitation of available research instruments as well as the development of new, more innovative ones.

\section{LITERATURE}

Allen, J. A. (1966). Scientific innovation and industrial prosperity. London, Great Bitain: Longman.

Aumann, R. J. (1962). Utility Theory without the Completeness Axiom. Econometrica, 30(3), 445-462.

Baumol, J. W. (2007). Entrepreneurship and Innovation: The (Micro) Theory of Price and Profit. Retrieved from https:// www.aeaweb.org/annual_mtg_papers/2008/2008_345. pdf

Borch, K. H. (1990). Economics of insurance. Amsterdam, Netherlands: Elsevier Science Publishers B.V.

Borowski, P. F. (2011). Przedsiębiorstwa XXI wieku [21st Century Enterprises]. Europejski Doradca Samorządowy, 17(2), 8-13.

Cavagnoli, A. (2011). Conceptual Framework For Innovation: An Application to Human Resource Management Policies in Australia. Innovation: Management, Policy \& Practice, 13(1), 111-125.

Chang, H., Kopaska-Merkel, D., \& Chen, H. (2002). Identification of lithofacies using Kohonen selforganizing maps. Computers and Geosciences, 28, 223-229.

Czechowicz, A., \& Mikut, Z. (2007). Wykorzystanie sieci Kohonena do selekcji podobrazów na potrzeby dopasowania zdjęć lotniczych [Use of Kohonen Network for the Selection of Sub-Images for the Purpose of Matching Aerial Photos]. Automatyka, 11(3), 329-340.

Drucker, P. (1992). Innowacja i przedsiębiorczość, praktyka $i$ zasady [Innovation and Entrepreneurship; Practice and Principles]. Warszawa, Poland: PWE.

Hebb, D. (1949). The Organization if Behavior. New York, USA: John Wiley \& Sons Inc.

Jajuga, K. (2007). Zarządzanie ryzykiem [Risk Management]. Warszawa, Poland: Wydawnictwo Naukowe PWN.

Kahneman, D., \& Tversky, A. (1979). Prospect Theory: An Analysis of Decision under Risk. Econometrica, 47(2), 263-292.

Kasperski, M. J. (2003). Sztuczna inteligencja [Artificial Intelligence]. Gliwice, Poland: Wydawnictwo HELION.

Kaszuba-Perz, A., \& Perz, P. (2010). Rola zarządzania ryzykiem w przedsiębiorstwie w obliczu wzrostu zewnętrznych czynników ryzyka, [The Role 
of Risk Management at an Enterprise in the Face of Increasing External Risk Factors]. Finansowy Kwartalnik Internetowy „e-Finanse”, 6(2). Retrieved from http://www.e-finanse.com/artykuly/144.pdf

Knight, F. (1921). Risk, uncertainty and profit. Boston, USA: Hart, Schaffner \& Marx; Houghton Mifflin Co.

Kohonen, T. (1982). Self-Organized Formation of Topologically Correct Feature Maps. Biological Cybernetics, 43(1), 59-69. doi: 10.1007/BF00337288

Kohonen, T. (1995). Self-Organizing Maps. Heidelberg, Germany: Springer.

Kraszewska, M. (2011). Zastosowanie sieci neuronowych do wyceny kontraktów opcyjnych na indeks WIG20 [Application of Neural Networks for Pricing Option Contracts for WIG20 Index]. Pomiary, Automatyka, Robotyka, 12, 220-222.

Kwiecień, I. (2010). Ubezpieczenia w zarządzaniu ryzykiem działalności gospodarczej [Insurance in Economic Activity Risk Management]. Warszawa, Poland: C.H. Beck.

Larose, D. T. (2006). Odkrywanie wiedzy $z$ danych. Wprowadzenie do eksploracji danych [Discovering Knowledge from Data. Introduction to Data Exploration]. Warszawa, Poland: Wydawnictwo Naukowe PWN.

Larose, D. T. (2009). Data Mining Methods and Models. New Jersey, USA: A John Wiley \& Sons, Inc.

Lasek, M., \& Myzik, A. (2004). Sieci neuronowe Kohonena w przeprowadzaniu analiz danych. Próba wykorzystania w eksploracji danych dotyczących jednostek terytorialnych [Kohonen Neural Networks in Carrying Out Data Analyses. An Attempt to Use Data Concerning Territorial Units in Exploration]. Problemy Zarządzania, 10(3(38), 124-147.

Licznar, P., \& Łomotowski, J. (2006)Zastosowanie sztucznych sieci neuronowych Kohonena do prognozowania dobowego poboru wody [Application of Kohonen Artificial Neural Networks to Forecast Daily Water Intake]. Ochrona Środowiska, 28(1), 45-48.

Marciniak, S. (2010). Innowacyjność i konkurencyjność gospodarki [Innovativeness and Competitiveness of Economy]. Warszawa, Poland: C.H. Beck.

Markowitz, H. M. (1959). Portfolio selection - efficient diversification of investment. New Haven, USA: Yale University Press.

McCulloch, W., \& Pitts, W. (1943). A logical calculus of the ideas immanent in nervous activity. Bulletin of Mathematical Biophusics, 5, 115-133.

Monkiewicz, J., \& Gąsiorkiewicz, L. (2011). Ubezpieczenia w zarzadzaniu ryzykiem przedsiębiorstwa. Zastosowania [Insurance in Corporate Risk Management. Applications]. Warszawa, Poland: Poltex.

Monkiewicz, J., \& Hadyniak, B. (2010). Ubezpieczenia w zarządzaniu ryzykiem przedsiębiorstwa [Insurance in Corporate Risk Management]. Warszawa, Poland: Poltex.

Muczyński, A. (2009). Grupowanie nieruchomości wspólnot mieszkaniowych z wykorzystaniem sieci Kohonena [Grouping Housing Communities' Real Estate through the Use of Kohonen Network]. Acta Sci. Pol. Administratio Locorum, 8(4), 5-15.
Neuman, J., \& Morgenstern, O. (1944). Theory of Games and Economic Behavior. Princeton Classic Editions, Paperback - Deluxe Edition (2007).

Pichlak, M. (2012). Uwarunkowania innowacyjności organizacji. Studium teoretyczne $i$ wyniki badań [Conditions of Corporate Innovativeness. A Theoretical Study and Research Results]. Warszawa, Poland: Difin.

Pukała, R. (2013). Insurance in corporate risk management. In Borowiecki R., Jaki A., \& Rojek T. (Eds.), Contemporary economies In the face of New challenges. Economic, social and legal aspects (pp. 283-298). Cracow, Poland: Cracow University of Economics, Foundation of the Cracow University of Economic.

Pukała, R. (2014). Insurance as a tool for limiting corporate operational risk. In Jaki A., \& Mikuła B. (Eds.), Knowledge - Economy - Society, Managing organizations: concepts and their applications (pp. 143-155). Cracow, Poland: Cracow University of Economics, Foundation of the Cracow University of Economic.

Qutreville, J. F. (1998), Theory and practice of insurance. Kluwer Academic Publishing.

Ramsey, F. P. (1926). Truth and probability. In Kyburg H. E., \& Smokler H. E. (Eds.), Studies in Subjective Probability (pp. 23-52). Robert E. Krieger Publishing Co., Inc.

Rogers, E. M. (2003). Diffusion of innowations. New York, USA: Free Press.

Ronka-Chmielowiec, W. (1998). Analiza $i$ metody zmniejszania ryzyka $w$ polskim systemie ubezpieczeń majatkowych [Analysis and Methods of Reducing Risk in the Polish Property Insurance System]. Wrocław, Poland: Uniwersytet Ekonomiczny.

Sadowski, W. (1978). Podstawy ogólnej teorii systemów [Fundamentals of general systems theory]. Warszawa, Poland: PWN.

Schumpeter, J. A. (1960). Teoria rozwoju gospodarczego [Economic Development Theory]. Warszawa, Poland: PWN.

Sudoł, S. (2006). Przedsiębiorstwo. Podstawy nauki o przedsiębiorstwie. Zarządzanie przedsiębiorstwem [Enterprise. Basics of Enterprise Science. Corporate Management]. Warszawa, Poland: PWE.

Tadeusiewicz, R. (1998). Elementarne wprowadzenie do techniki sieci neuronowych $z$ przykładowymi programami [Elementary Introduction to the Neural Networks Technique with Software Examples]. Warszawa, Poland: Akademicka Oficyna Wydawnicza PLJ.

Tadeusiewicz, R. (2007). Odkrywanie własności sieci neuronowych przy użyciu programów w języku C+, [Discovering Features of Neural Networks by means of C+ Language Software]. Kraków, Poland: Polska Akademia Umiejętności.

The measurement of scientific and technological activities proposed guidelines for collecting and interpreting technological innovation data. Oslo Manual, European Commission. Retrieved from http://www. oecd.org/sti/inno/2367580.pdf

Vaughan, E. (1997). Risk Management. New York, USA. 
Whitfield, P. R. (1979). Innowacje w przemyśle [Innovations in Industry]. Warszawa, Poland: PWE.

Wiśniewska, J., \& Janasz, K. (2012). Innowacyjność organizacji wstrategii inteligentnego izrównoważonego rozwoju [Innovations of Organisations as part of Intelligent and Sustainable Development Strategy]. Warszawa, Poland: Difin.

Zaród, J. (2012). Zastosowanie sieci Kohonena do podziału województwa zachodniopomorskiego na rejony o zbliżonych warunkach produkcji rolniczej [Application of Kohonen Network for the Division of West-Pomeranian Voivodeship into Regions with Similar Agricultural Production Conditions]. Folia Pomeranae Universitatis Technologiae Stetinensis., Univ. Technol. Stetin. Oeconomica, 297(68), 107-116.

Zarządzanie ryzykiem i ubezpieczeniami w Polsce [Corporate Risk and Insurance Management in Poland], (2016). Report prepared by Aon Risk Solution. Retrieved from http://www.aon.com/ poland/risk/Aon\%20Thought\%20Leadership/ Zarzadzanie-ryzykiem-i-ubezpieczeniami-wPolsce-IV-edycja.jsp

Zastempowski, M. (2010). Uwarunkowania budowy potencjału innowacyjnego polskich małych i średnich przedsiębiorstw [Conditions of Building Innovation Potential among Small and Medium-Sized Enterprises in Poland]. Toruń, Poland: UMK. 